\title{
EFEKTIVITAS PENGGUNAAN MODUL KERANG MUTIARA BERBASIS PENDEKATAN SAINTIFIK TERHADAP HASIL BELAJAR SISWA PADA MATA PELAJARAN BUDIDAYA DI SMKN 1 LEMBAR
}

\section{EFFECTIVENESS OF USING PEARL OYSTER MODULE BASED ON SCIENTIFIC APPROACH TO STUDENT LEARNING RESULT ON CULTIVATION LESSON IN SMKN 1 LEMBAR}

\author{
Septi Suryaningsih, Muhlis, Jamaluddin \\ Prodi Pendidikan IPA, Magister Pendidikan IPA, Universitas Mataram, Mataram \\ Email:
}

Diterima: 28 Agustus 2017. Disetujui 7 September 2017. Dipublikasikan: 30 September 2017

\begin{abstract}
Abstrak. Penelitian ini bertujuan: untuk mengetahui efektivitas modul kerang mutiara berbasis pendekatan santifik terhadap hasil belajar siswa pada mata pelajaran budidaya di SMKN 1 Lembar, Lombok Barat. Penelitian ini menggunakan metode eksperimen semu. Penelitian ini dianalisis secara deskriptif persentase. Tingkat ketuntasan klasikal siswa $100 \%$ dengan rata-rata hasil belajar siswa sebesar $88,74 \%$, Sehingga modul kerang mutiara berbasis pendekatan saintifik yang dikembangkan memenuhi kriteria standar penilaian bahan ajar dan efektif digunakan dalam pembelajaran siswa kelas XI SMKN 1 Lembar berbasis kemaritiman yang memiliki KKM $\geq 80$.
\end{abstract}

Kata Kunci: Modul kerang mutiara, Pendekatan Saintifik, Evektifitas hasil belajar

\begin{abstract}
This study aims to determine the effectiveness of pearl oyster module based on a santifik approach to student learning outcomes on cultivation subjects in SMKN 1Lembar, West Lombok. This research uses quasi experimental method. This research is analyzed descriptively percentage. Student classical completeness was $100 \%$ with average student learning outcomes of $88.74 \%$. It is indicates that the pearl oyster module based on the developed scientific approach meets the criteria of the standard assessment of the teaching materials. It is effectively used in the learning of the class XI SMKN 1 Lembar based maritime which has classical completeness $\geq 80$.
\end{abstract}

Keywords: module oyster, scientifik approach, learning outcomes effectivenes

\section{PENDAHULUAN}

Mutiara air laut merupakan salah satu komoditas unggulan di Provinsi Nusa Tenggara Barat (NTB), hal ini tertera dalam data DISPERINDAG Provinsi Nusa Tenggara Barat tahun 2015 yaitu, mencapai nilai rata-rata 0,295 ton per lima tahun terakhir. Sehingga usaha budidaya kerang mutiara memiliki prospek masa depan yang cerah. Disamping itu mutiara merupakan komoditas sektor perikanan yang bernilai ekonomis tinggi, dan memiliki prospek pengembangan di masa datang [1].

Budidaya kerang mutiara di Wilayah Nusa Tenggara Barat didominasi oleh pengusaha Asing, ataupun bukan masyarakat sekitar wilayah pesisir pantai [2]. Hal ini disebabkan karena kurangnya informasi dan keterampilan, serta modal usaha di kalangan masyarakat lokal. Oleh karena itu, perlu adanya sumber daya manusia yang ahli dibidang budidaya kerang mutiara. Dengan mempelajari modul tentang budidaya kerang mutiara yang berbasis pendekatan saintifik, akan menjadi salah satu sumber belajar bagi siswa yang sekolah di Sekolah Menengah Kejuruan berbasis kemaritiman. Guna untuk meningkatkan sumber daya manusia yang diperlukan, pada budidaya kerang mutiara. Sehingga modul ini perlu diajarkan sebagai materi pembelajaran pada mata pelajaran budidaya di Sekolah Menengah Kejuruan Negeri 1 Lembar yang berbasis Kemaritiman.

Melalui pendekatan saintifik, diharapkan siswa mampu merancang sedemikian rupa teknik budidaya kerang mutiara secara aktif melalui tahapan-tahapan mengamati, menanya, mencoba, menalar, dan mengkomunikasikan konsep, hukum atau prinsip yang ditemukan melalui Kurikulum 2013 di Sekolah Menengah Kejuruan.

[3]Permendikbud No. 79 tahun 2014 menyatakan bahwa muatan lokal merupakan bahan kajian, atau mata pelajaran pada satuan pendidikan yang berisi muatan dan proses pembelajaran tentang potensi dan keunikan lokal, yang dimaksudkan untuk membentuk pemahaman siswa terhadap keunggulan dan kearifan di daerah 
tempat tinggalnya. Sehingga materi tentang budidaya kerang mutiara juga dapat dijadikan sebagai materi muatan lokal. Untuk membentuk pemahaman siswa terhadap keunggulan dan kearifan lokal di Sekolah Menengah Kejuruan yang ada di Provinsi Nusa Tenggara Barat.

Proses pembelajaran dapat terlaksana dengan baik jika adanya bahan ajar yang memadai, salah satu bahan ajar yang baik adalah modul [4]. Modul kerang mutiara yang berbasis pendekatan saintifik yang menitik beratkan pada kegiatan menanya, mengamati, menalar, mencoba dan mengkomunikasikan [5] akan berpengaruh terhadap hasil belajar siswa di SMKN 1 Lembar. Modul kerang mutiara disusun berdasarkan kurikulum Sekolah Menengah Kejuruan yang ada di SMKN 1 Lembar, sehingga modul kerang mutiara dikembangkan berdasarkan bahan ajar pada mata pelajaran budidaya yang ada di SMKN 1 Lembar. Tujuan penelitian ini adalah Untuk mengetahui pengaruh modul kerang mutiara berbasis pendekatan santifik terhadap hasil belajar siswa pada mata pelajaran budidaya di SMKN 1 Lembar.

\section{METODE PENELITIAN}

Jenis penelitian ini adalah eksperimen semu dengan rancangan penelitian One Group PretestPostest. Populasi dalam penelitian ini adalah semua siswa kelas XI SMKN 1 Lembar yang terdaftar pada tahun 2016/2017 terdiri dari 5 kelas. Sampel dari penelitian ini adalah kelas XI AP jurusan budidaya. Analisis data menggunakan perhitungan $\mathrm{N}$ - gain dengan rumus berikut:

$$
\mathrm{N} \text {-gain }=\frac{\text { Nilai posttest }- \text { Nilai pretest }}{\text { Skor ideal-Nilai pretest }}
$$

Prosedur penelitian dibagi menjadi 3 tahap [6] yaitu persiapan, pelaksanaan, penyelesaian. Pada tahap persiapan dilakukan kegiatan: observasi sekolah yang berbasis kemaritiman, mengajukan pelaksanaan penelitian, konsultasi dengan guru mata pelajaran budiaya, menetukan jadwal penelitian, mempersiapkan modul yang akan diberikan kepada siswa, mempersiapkan rencana pelaksanaan pembelajaran (RPP), mempersiapkan instrument penelitian berupa soal pre-test dan post-test. Tahap pelaksanaan kegiatan belajar mengajar menggunakan modul dengan melaksanakan kegiatan belajar tahap satu sampai dengan kegiatan belajar 5. Tahap penyelesaian dengan post-test.

Instrument yang digunakan dalam penelitian ini adalah soal pre-test dan post-test hasil belajar.

\section{HASIL DAN PEMBAHASAN}

Hasil belajar siswa pada penelitian ini berupa nilai pre-test post-test dan ketuntahasan hasil belajar siswa

Dengan KKM $\geq 80$. (KKM Kompetensi Dasar SMKN 1 Lembar tahun 2016). Hasil belajar siswa dapat dilihat pada Tabel 1 sampai dengan Tabel 5.

Tabel 1. Hasil kegiatan belajar 1

\begin{tabular}{|c|c|c|c|c|c|c|c|}
\hline \multirow[t]{2}{*}{ Kelas } & \multicolumn{2}{|c|}{ Nilai rata-rata } & \multirow[t]{2}{*}{ N-Gain } & \multicolumn{2}{|c|}{ Nilai tertinggi } & \multicolumn{2}{|c|}{ Nilai terendah } \\
\hline & Pre-test & Post-test & & Pre-test & Post-test & Pre-test & Post-test \\
\hline $\mathrm{XI}$ & 32,5 & 88,13 & 82 & 60 & 90 & 10 & 80 \\
\hline
\end{tabular}

Tabel 2. Hasil kegiatan belajar 2

\begin{tabular}{|c|c|c|c|c|c|c|c|}
\hline \multirow[t]{2}{*}{ Kelas } & \multicolumn{2}{|c|}{ Nilai rata-rata } & \multirow[t]{2}{*}{ N-Gain } & \multicolumn{2}{|c|}{ Nilai tertinggi } & \multicolumn{2}{|c|}{ Nilai terendah } \\
\hline & Pre-test & Post-test & & Pre-test & Post-test & Pre-test & Post-test \\
\hline XI & 35 & 89,38 & 83 & 50 & 100 & 10 & 80 \\
\hline
\end{tabular}

Tabel 3. Hasil kegiatan belajar 3

\begin{tabular}{|c|c|c|c|c|c|c|c|}
\hline \multirow[t]{2}{*}{ Kelas } & \multicolumn{2}{|c|}{ Nilai rata-rata } & \multirow[t]{2}{*}{ N-Gain } & \multicolumn{2}{|c|}{ Nilai tertinggi } & \multicolumn{2}{|c|}{ Nilai terendah } \\
\hline & Pre-test & Post-test & & Pre-test & Post-test & Pre-test & Post-test \\
\hline XI & 37,5 & 88,13 & 81 & 50 & 100 & 20 & 80 \\
\hline
\end{tabular}


Tabel 4. Hasil kegiatan belajar 4

\begin{tabular}{|c|c|c|c|c|c|c|c|}
\hline \multirow[t]{2}{*}{ Kelas } & \multicolumn{2}{|c|}{ Nilai rata-rata } & \multirow[t]{2}{*}{ N-Gain } & \multicolumn{2}{|c|}{ Nilai tertinggi } & \multicolumn{2}{|c|}{ Nilai terendah } \\
\hline & Pre-test & Post-test & & Pre-test & Post-test & Pre-test & Post-test \\
\hline XI & 35,63 & 88,75 & 82 & 40 & 100 & 30 & 80 \\
\hline
\end{tabular}

Tabel 5. Hasil kegiatan belajar 5

\begin{tabular}{|c|c|c|c|c|c|c|c|}
\hline \multirow[t]{2}{*}{ Kelas } & \multicolumn{2}{|c|}{ Nilai rata-rata } & \multirow[t]{2}{*}{ N-Gain } & \multicolumn{2}{|c|}{ Nilai tertinggi } & \multicolumn{2}{|c|}{ Nilai terendah } \\
\hline & Pre-test & Post-test & & Pre-test & Post-test & Pre-test & Post-test \\
\hline XI & 38,13 & 89,33 & 82 & 50 & 100 & 20 & 80 \\
\hline
\end{tabular}

Hasil belajar siswa digunakan untuk mengetahui kefektifan modul kerang mutiara berbasis pendekatan saintifik Hasil belajar siswa diperoleh dari gabungan antara nilai tes formatif siswa dan nilai evaluasi akhir. Pembelajaran dilakukan selama 6 (enam) kali pertemuan. Hal itu dilakukan berdasarkan masukan dari pembimbing, guru mata pelajaran budidaya dan sekolah dengan alasan penelitian yang dilakukan tidak mengganggu sistem pembelajaran yang sudah dibuat di sekolah serta berdasarkan jadwal pelajaran pada kelas XI AP.

Penilain penguasaan konsep siswa bertujuan untuk mengetahui sejauh mana kegiatan belajar mengajar telah berjalan secara efektif, dimana keefektivan pembelajaran akan tampak pada kemampuan siswa dalam mencapai tujuan belajar yang telah ditetapkan [7]. Untuk mengetahui perbedaan terhadap hasil belajar tentang penguasaan konsep pada modul kerang mutiara berbasis pendekatan saintifik, siswa diberikan tes awal (pre-test) bertujuan untuk mengetahi penguasaan konsep awal siswa sebelum diberikannya materi tentang pembelajaran, kemudian diberikan tes akhir (post-test) untuk mengetahui penguasaan konsep yang ada pada modul kerang mutiara dengan pendekatan saintifik.

Nilai pre-test dan post-test penguasaan konsep siswa sebelum dan sesudah penggunaan modul kerang mutiara berbasis pendekatan santifik mengalami perbedaan. Analisis nilai pretest siswa bertujuan untuk mengetahui penguasaan konsep awal [8]. Sedangkan analisis nilai post-test untuk mengetahui peningkatan hasil belajar siswa setelah menggunakan modul kerang mutiara berbasis pendekatan santifik. Berdasarkan analisis $\mathrm{N}$-gain penguasaan konsep siswa menunjukkan nilai 82 dengan kategori tinggi untuk hasil analisis pada kegiatan belajar 1 .

Kegiatan belajar 1 pada modul berisi tentang klasifikasi tentang kerang mutiara, morfologi kerang mutiara, anatomi kerang mutiara dan makanan dari kerang mutiara. Pada kegiatan belajar 1 dipilih materi dengan tujuan agar siswa dapat menentukan bagian anatomi kerang mutiara, menjelaskan ciri-ciri morfologi kerang mutiara, dan dapat membedakan antara bagian anatomi dengan morfologi kerang mutiara.

Pada kegiatan belajar 1, nilai rata-rata post-test adalah 88,13 . Berdasarkan nilai tersebut maka penggunaan modul kerang mutiara berbasis pendekatan saintifik dapat dikatakan tuntas dengan $\mathrm{KKM} \geq 80$.

Kegiatan belajar 2 bertujuan untuk menuliskan persyaratan lokasi secara geografis, persyaratan lokasi secara Teknik, persyaratan lokasi secara biologi dan kelayakan lokasi pemeliharaan kerang mutiara. Berdasarkan hasil penelitian pada kegiatan belajar 2, nilai rata-rata post-test adalah 89,38 dan analisi $\mathrm{N}$-gain sebesar 83 dengan kategori tinggi untuk kegiatan belajar 2.

Analisis N-gain untuk kegiatan belajar 3 dengan nilai 81 dikategorikan tinggi. Nilai ratarata post-test 88,13 dengan kategori tinggi. Pada kegiatan belajar 3 ini diharapkan siswa dapat merumuskan syarat-syarat penyediaan bibit kerang mutiara. Menurut [9] populasi kerang mutiara di alam saat ini mengalami penurunan karena perubahan kondisi alam yang ekstrim dan kemampuan kerang mutiara untuk meningkatkan jumlah populasi semakin berkurang dan sulit untuk ditemukan. Ditinjau berdasarkan sulitnya memperoleh kerang mutiara alam oleh karena itu materi pada modul kerang mutiara perlu adanya materi tentang penyediaan bibit kerang mutiara budidaya dan siswa diberikan materi tentang cara pemilihan bibit kerang mutiara yang baik serta cara pengukuran pembelian dan penjualan bibit kerang mutiara.

Kegiatan belajar 4 menitik beratkan pada pembuatan mutiara budiaya dengan tujuan pembelajaran siswa diharapkan dapat menyebutkan proses pembuatan mutiara budidaya. pada kegiatan belajar ini analisis $\mathrm{N}$-gain sebesar 82 dan nilai rata-rata post-test adalah 88,75 dengan kriteria tinggi. Kegiatan belajar 4 
menyajikan materi yang paling penting dalam penghasilan mutiara. Mutiara yang dihasilkan oleh kerang mutiara tidak akan terbentuk dengan baik jika tidak adanya penangan yang tepat saat penyuntikan dan pemeliharaan pasca penyuntikan.

Melalui pembelajaran pada kegiatan 5 diharapkan siswa dapat memperkirakan hasil penjualan mutiara berdasarkan hasil panen. Pada kegiatan belajar 5 materi yang disajikan adalah pemanenan dan penanganan mutiara hasil budidaya serta pemanfaatan cangkang kerang mutiara. Penerapan modul kerang mutiara berbasis pendekatan saintifik pada siswa kelas XI AP di SMKN 1 Lembar memiliki nilai rata-rata post-test sebesar 89,75 dan anailis $\mathrm{N}$-gain 82 yang berarti dapat dikategorikan tinggi.

Berdasarkan secara keseluruhan untuk kegiatan belajar 1 sampai dengan kegiatan belajar 2, menunjukkan bahwa analisis $\mathrm{N}$-gain dikategorikan tinggi dan rata-rata nilai $K K M \geq 80$. Hasil belajar siswa dapat dikatakan tuntas jika ditinjau berdasarkan nilai KKM. Nilai $\mathrm{KKM} \geq 80$ adalah standar yang ditentukan untuk sekolah menegah kejuruan yang siswanya telah pada penjurusan [10].

Berdasarkan Tabel 1 samapi 5 dapat diketahui bahwa pembelajaran menggunakan modul kerang mutiara berbasis pendekatan saintifik menunjukan hasil positif. Hal tersebut terlihat dari jumlah siswa yang tuntas sebanyak 16 siswa dengan ketuntasan belajar siswa secara klasikal $100 \%$ termasuk dalam kriteria "sangat baik" dan nilai rata-rata 88,75. Keberhasilan penggunaan modul kerang mutiara berbasis pendekatan saintifik dikarenakan siswa dapat memahami modul yang disajikan. Hasil tersebut membuktikan modul kerang mutiara berbasis pendekatan saintifik efektif digunakan untuk siswa SMK kelas XI. Kondisi ini sesuai dengan pembahasan [11] bahwa penggunaan modul pelajaran merupakan sumber belajar pokok atau bahan ajar wajib bagi siswa yang juga mampu memudahkan siswa dalam memahami materi yang bersifar abstrak.

\section{KESIMPULAN}

Penggunaan modul kerang mutiara berbasis pendekatan saintifik efektif digunakan di SMK kelas XI pada jurusan agrobisnis perikanan. Ketuntasan hasil belajar secara klasikal mencapai $100 \%$ dengan nilia rata-rata siswa $88,74 \%$. Nilai siswa sesuai dengan standar $\mathrm{KKM} \geq 80$.

\section{SARAN}

Untuk meningkatakan pelaksanaan dan penerapan modul ini disarankan penggunaan modul secara bertahap, karena akan meningkatkan kemampuan siswa untuk memahami materi tentang budidaya kerang mutiara

\section{DAFTAR PUSTAKA}

[1] Awaluddin M, Yuniarti S, \& Mukhlis A. 2013. Tingkat Penetasan Telur \& Kelangsungan Hidup Larva Kerang Mutiara (Pincatda maxima) Pada Salinitas yang Berbeda. Kelautan: 06.02

[11]Fitriyati, N. 2011. Pengembangan Bahan Ajar Berbentuk Komik Berpendekatan JAS Meteri Sistem Hormon di SMP 2 Mejobo Kudus. Skripsi. Semarang: Jurusan Biologi FMIPA Unnes

[7]Jufri, A., W. 2013. Belajar dan Pembelajaran Sains. Pustaka Reka Cipta: Bandung.

[10]Kemendikbud (Kementerian Pendidikan dan Kebudayaan). 2013, Konsep Pendekatan saintifik. Diklat Guru. Kementerian Pendidikan dan Kebudayaan.

[5]Sani, R., A. 2014. Pembelajaran Saintifik untuk implementasi kurikulum 2013. Bumi Aksara. Jakarta

[9]Syachruddin A.,R, (2006). Peningkatan Produksi Mutiara Melalui Pembesaran Bibit Kerang Mutiara di Perairan Kota Bima NTB. Makalah Seminar Bapenas Program Local EconomicResourcces Development (LERD). Jakarta

[3]Permendikbud (Peraturan Menteri Pendidikan dan Kebudayaan) Republik Indonesia. 2013. Permendikbud No. 81a Tahun 2013 tentang Implementasi Kurikulum Pedoman Umum Pembelajaran. Pdf. Jakarta: Kementerian Pendidikan dan Kebudayaan

[4]Purwanto. 2007. Pengembangan Modul. Jakarta: PUSTEKOM Depdiknas.

[2]Radiarta, N., I. 2013. Hubungan Antara Distribusi Fitoplankton dengan Kualitas Perairan di Selat Alas Kabupaten Sumbawa Nusa Tenggara Barat. Bumi Lestari, 13 (2), 234-243.

[7]Yanurdanti., 2013. Peningkatan Efektifitas Pembelajaran IPA Terpadu Melalui Penggunaan Modul Berbasis Saling Temas Materi Cahaya dan Mata dengan Tema Cahaya dan Manfaatnya. Surakarta: Universitas Sebelas Maret

[6]Yerita., H., Haviz., M., \& Rahmi., E.2014. Efektivitas Penggunaan Modul Pembelajaran Biologi Berbasis Kontekstual Pada Pokok Bahasan Ekosistem Siswa Kelas X di SMAN 1 Rambatan. 